\title{
EPIDEMIOLOGY AND SURVIVAL ANALYSIS OF MOUTH AND \\ OROPHARYNGEAL CANCER PATIENTS TREATED AT A PUBLIC \\ HOSPITAL IN RIO DE JANEIRO, BRAZIL.
}

\author{
Jackeline Nogueira de Paula Barros \\ Habilitada em Odontologia Hospitalar - CFO/RJ e CEMOI \\ Especialista em Cirurgia e Traumatologia Bucomaxilofacial - FO-CESVA/FAA \\ Mestre em Clínica Odontológica pela UFRJ - Rio de Janeiro \\ Staff do Hospital Municipal Salgado Filho - Rio de Janeiro
}

\section{Joberth Rainner Baliza de Paula}

Cirurgião-dentista pela Faculdade Federal Fluminense - UFF

\section{Catarina Luzia dos Santos José Monteiro}

Cirurgiã-dentista pela Faculdade do Grande Rio - Unigranrio

\section{Jéssica Pronestino de Lima Moreira}

Mestre em Saúde Coletiva pela UFRJ - Rio de Janeiro

Doutora em Engenharia Biomédica pela COPPE/UFRJ - Rio de Janeiro

Categoria: Estudo Retrospectivo

\section{Autor Correspondente:}

\section{Jackeline Nogueira de Paula Barros}

Hospital Municipal Salgado Filho

Rua Arquias Cordeiro, 370 - Méier - Rio de janeiro - RJ

Telefone: (21) 98106-8890

jackelinenpb@gmail.com 


\begin{abstract}
Mouth and oropharyngeal cancers (CAs) are considered to be global public health problems, with high psychosocial impacts and high costs. Developing an epidemiological profile and examining the survival rate among patients with CAs of the mouth and oropharynx are important for the development of public policy. Therefore, this retrospective study aimed to evaluate mouth and oropharyngeal CA patients treated at the Municipal Hospital Salgado Filho in Rio de Janeiro, Brazil between 2007 and 2017. Patient data regarding gender, age, ethnicity, diagnosis, anatomical site affected by the tumor, and habits were obtained from patient records and reports, and data regarding the deaths of patients were obtained from records and the Mortality Information System. After tabulation, data were descriptively analyzed using the Kaplan-Meier survival curve, and the log-rank test was used for the comparison of variables. Survival rates at 5 and 8 years were $71.1 \%$ and $48.8 \%$, respectively. There were no significant differences among survival rates according to age, sex, ethnicity, or the anatomical location of tumors. The survival rates among mouth and oropharyngeal CA patients in this study were comparable with the results reported in developed countries.
\end{abstract}

Keywords: Oral neoplasms, epidemiology, survival rate;

\title{
INTRODUCTION
}

Mouth cancer (CA), also known as lip CA and oral CA, covers a set of malignancies that affect the lips, gums, cheeks, hard palate, tongue, and mouth floor. Oropharyngeal CA affects the posterior part of the tongue, tonsils and soft palate, with different oral cavity CA behaviors and different etiologies and histopathological aspects from those associated with mouth CA (INCA, 2019). Mouth and oropharyngeal CAs are considered to be serious global public health problems, due to their high incidences and prevalences, high psychosocial impacts and the high costs of treatment (BOING, AF \& ANTUNES, JLF, 2011).

In Brazil, according to the National Cancer Institute (INCA), the estimated number of cases of mouth CA during 2018-2019 was 14,700, including 11,200 men and 3,500 women, making mouth CA the fourth most commonly occurring CA type. These values correspond to estimated risks of 10.86 new cases per 100,000 men and 3.28 per 
100,000 women. In 2015, there were 4,672 deaths from oral cavity CA in men and 1,226 deaths in women (INCA, 2019).

Squamous cell carcinoma (SCC), also called spinocellular or epidermoid carcinoma, is the most common malignant neoplasm in the mouth and oropharynx, representing $80-90 \%$ of all oral cavity CA cases. SCC is most frequently found on the posterior lateral border of the tongue and on the floor of the mouth in adult male patients over 40 years of age but may also occur in other, less frequently involved sites, such as the soft palate, gingiva, jugal mucosa, labial mucosa, and hard palate (NEVILLE, 2016).

The etiology of oral cavity CA is multifactorial, including both intrinsic and extrinsic factors. However, tobacco and alcohol use represent the most important etiological factors; although isolated alcohol consumption cannot be considered a carcinogenic factor, the combination of tobacco and alcohol use represents a major risk for oral cavity CA (ANDRADE, J, et al., 2015). In addition, studies by Sobral et al. (2014) have demonstrated a close relationship between HPV and oral cavity CAs, revealing an important role played by HPV in the pathogenesis of oral cavity CAs.

The clinical presentations of oral cavity CAs vary, ranging from simple leukoplakia lesions to persistent ulcers, which occur more frequently. Pain is generally absent or minimal during the early stages, which may justify delaying medical attention and, consequently, result in worse prognoses (NEVILLE, 2016).

Early diagnosis is easy, but the silent nature of the lesions and late identification, due to delays in the acquisition of health services, often lead to the lesions reaching advances stages. Early diagnosis, rapid referral and access to specialized services are important factors in reducing the morbidity and mortality associated with these CAs, resulting in the use of more conservative treatments and contributing to improvements in survival rates (SOUZA TORRES, SV, et al., 2016).

The importance of epidemiological studies is justified by the large lethality index. Epidemiological studies can facilitate the characterization of populations at risk, and provide the necessary information for optimizing and defining public health policies aimed at oral cavity CA prevention, protection and treatment (CASOTTI, E, et al., 2016).

The objective of this study was to establish an epidemiological profile and determine the survival rates for patients with CA of the mouth and oropharynx, as diagnosed by biopsies and anatomopathological examinations, that were treated at the 
Salgado Filho Municipal Hospital (HMSF) in Rio de Janeiro, Brazil, between 2007 and 2017.

\section{METHODS}

A retrospective study was performed between 2007 and 2017, through the analysis of medical records and reports for patients who were diagnosed with mouth and oropharyngeal CA following a histopathological examination performed at Salgado Filho Municipal Hospital, which is a public and reference hospital, located in the municipality of Rio de Janeiro, Brazil.

This study received was approved by the Committee of Ethics in Research (CER) with Human Beings of the Municipal Health Secretariat of Rio de JaneiroSMS/RJ, under the number CAAE: 69625417.7.0000.5279, opinion no. 3,049,583. The study was performed by collecting data stored in medical records and files maintained by HMSF-RJ, with the aid of HospPub software and the digital information system used by the Department of Pathology at the referred hospital.

To understand the epidemiology of mouth and oropharyngeal CA, data regarding age, sex, ethnicity, habits, diagnosis, anatomical location, and place of residence, according to the area of the program (PA), were collected. Patients whose records were incomplete with regards to the studied variables and those who refused to participate in the study were excluded.

The variable of age was divided into categories by decade, while the variable of ethnicity was divided into the categories of white, brown and black and then dichotomized in whites and non-whites. The anatomical location of the tumor was considered according to the 2018 INCA classification guidelines (https://www.inca.gov.br/tipos-de-cancer-demouth), and the mortality data was obtained from medical records and the Mortality Information System (SIM) - DATASUS (Department of information technology of SUS)

Subsequently, the data were treated and analyzed descriptively using the Kaplan-Meier survival curve, from the date of diagnosis until the date of death or until the termination of the study, whichever occurred first. The log-rank test was used to compare the effects of age, ethnicity, sex and location of the tumor on survival. The program Statistical Package for Social Sciences (SPSS Inc., Chicago 1, IL, EUA) version 21.0 was used. 


\section{RESULTS}

We analyzed 173 medical records of patients diagnosed with CA of the mouth and oropharynx between 2007 and 2017, of which 156 presented complete data and were included in the study. Patients were $79.5 \%$ men and $20.5 \%$ women, with a mean age of $61 \pm 12.5$ years. Patients in their fifth decade of life were the most prevalent $(35.3 \%)$, with the youngest patient being 22 years old and the oldest being 91 years old. With regards to ethnicity, the majority (52.7\%) were non-white, with $40.0 \%$ brown and $12.7 \%$ black, and the remaining $47.3 \%$ were white. Of the patients included in the study, $86.5 \%$ lived in the municipality of Rio de Janeiro, while the remaining $13.5 \%$ lived elsewhere. (Table 1).

Table 1. Characteristics of patients with CA of the mouth and oropharynx between 2007 and 2017 in Rio de Janeiro, Brazil.

\begin{tabular}{lcc}
\hline Variables & Frequency & Percentage (\%) \\
\hline Sex & 32 & 20,5 \\
Female & 124 & 79,5 \\
Male & & \\
Ethnicity & 26 & 47,3 \\
White & 29 & 52,7 \\
No white brancos (brown and Black) & & \\
Age Group (years) & 21 & 13,5 \\
$\leq 49$ & 55 & 35,3 \\
$50-59$ & 42 & 26,9 \\
$60-69$ & 38 & 24,4 \\
$\leq 70$ & & 12,5 \\
\hline Mean age (years, standard deviation) & 61 & 3,5 \\
& & \\
City & 135 & 36,5 \\
Rio de Janeiro & 21 & \\
Other cities & & \\
& & \\
\hline
\end{tabular}


Oral SCC was the most common CA type identified (89.0\%), followed by adenocarcinoma (5.8\%) (Table 2$)$.

Table 2. Distribution of the most frequently identified types of malignant neoplasms in the oral cavity between 2007 and 2017 in Rio de Janeiro, Brazil.

\begin{tabular}{lcc}
\hline Type of cancer & Frequency & Percentage \\
\hline Epidermoid /Skin/ Spinocellular & 137 & 89,0 \\
Basocellular & 3 & 1,9 \\
Adenocarcinoma & 9 & 5,8 \\
Kaposi & 1 & 0,6 \\
Sarcoma & 1 & 0,6 \\
Hodgkin's lymphoma & 3 & 1,9 \\
Total & $\mathbf{1 5 6}$ & $\mathbf{1 0 0}$ \\
\hline
\end{tabular}

With regards to the anatomical locations of CAs, malignant neoplasms of the mouth $(79.5 \%)$ were more prevalent than those of the oropharynx, and the lingual region (36.3\%) was the most commonly affected, including the lateral portion (24.2\%) and the floor (16.\%), followed by the alveolar ridge (12.7\%). The intraoral region was affected in $89.9 \%$ of the CAs, with $21.2 \%$ of cases occurring on the right side, $23.1 \%$ of cases occurring on the left side and $3.2 \%$ of cases occurring bilaterally (Table 3 ).

Table 3. Distribution of the anatomical locations of malignant neoplasms, categorized by intra- and extraoral localization and right and left sides, in Rio de Janeiro, Brazil, from 2007 to 2017.

\begin{tabular}{lcc}
\hline Anatomical location & Frequency & Percentage $(\%)$ \\
\hline Mouth & $\mathbf{1 2 4}$ & $\mathbf{7 9 , 5}$ \\
lateral tongue & 36 & 24,2 \\
Back of tongue & 13 & 8,7 \\
Belly of tongue & 4 & 2,7 \\
Alveolar ridge & 19 & 12,8
\end{tabular}




$\begin{array}{lcc}\text { Floor } & 24 & 16,0 \\ \text { Lip } & 4 & 2,7 \\ \text { Gum } & 2 & 1,3 \\ \text { Hard palate } & 8 & 5,4 \\ \text { Oral mucosa } & 14 & 9,4 \\ \text { Oropharyngeal } & \mathbf{2 0} & \mathbf{1 3 , 4} \\ \text { Base of tongue } & 1 & 0,7 \\ \text { Amygdala } & 4 & 2,7 \\ \text { Soft palate } & 15 & 10,0 \\ \text { Other parts of the mouth } & \mathbf{5} & \mathbf{3 , 4} \\ \text { Intra Oral } & 134 & 89,9 \\ \text { Extra Oral } & 15 & 10,1 \\ \text { Both } & 1 & 0,6 \\ \text { Right side } & 32 & 43,8 \\ \text { Left side } & 35 & 48,0 \\ \text { Bilateral } & 6 & 8,2\end{array}$

With regards to alcohol consumption, $56.5 \%$ of the patients were chronic drinkers, $88.4 \%$ were smokers and $57.4 \%$ consumed both alcoholic beverages and cigarettes (Table $4)$.

Table 4. Distribution of Malignant Neoplasms of mouth and oropharynx according to consumption of alcoholic beverage and tobacco. Rio de Janeiro, Brazil, from 2007 to 2017.

\begin{tabular}{lcc}
\hline Habit & Prequency & Percentage (\%) \\
\hline Alcohol & 39 & 56,5 \\
Smoke & 61 & 88,4 \\
Concomitant & 39 & 57,4
\end{tabular}

Among the patients with mouth and oropharyngeal CA, 51.5\% of patients died within 8.4 years (101 months) from the time of diagnosis. The mean survival time was 72.0 months, which is equivalent to 6 years (95\% CI 64.22-79.955), with a mean survival time for men of 69.4 months (5 years and 7 months) and a mean survival time for women 
of 82.3 ( 6 years and 8 months) (Table 5). The survival rates at 5 and 8 years were $61.3 \%$ and $48.5 \%$, respectively (Figure 1).

Table 5. Distribution of survival times among patients with CAs in the mouth and oropharynx, according to sex, in Rio de Janeiro, Brazil, from 2007 to 2017.

\begin{tabular}{lcc}
\hline Time to Survive & Months & Years \\
\hline Male & 69,4 & 5,7 \\
Female & 82,3 & 6,8 \\
General & 72,0 & 6,0
\end{tabular}

Figure 1. Kaplan-Meier analysis for survival of patients with oral cancer. Rio de Janeiro, Brazil, from 2007 to 2017.

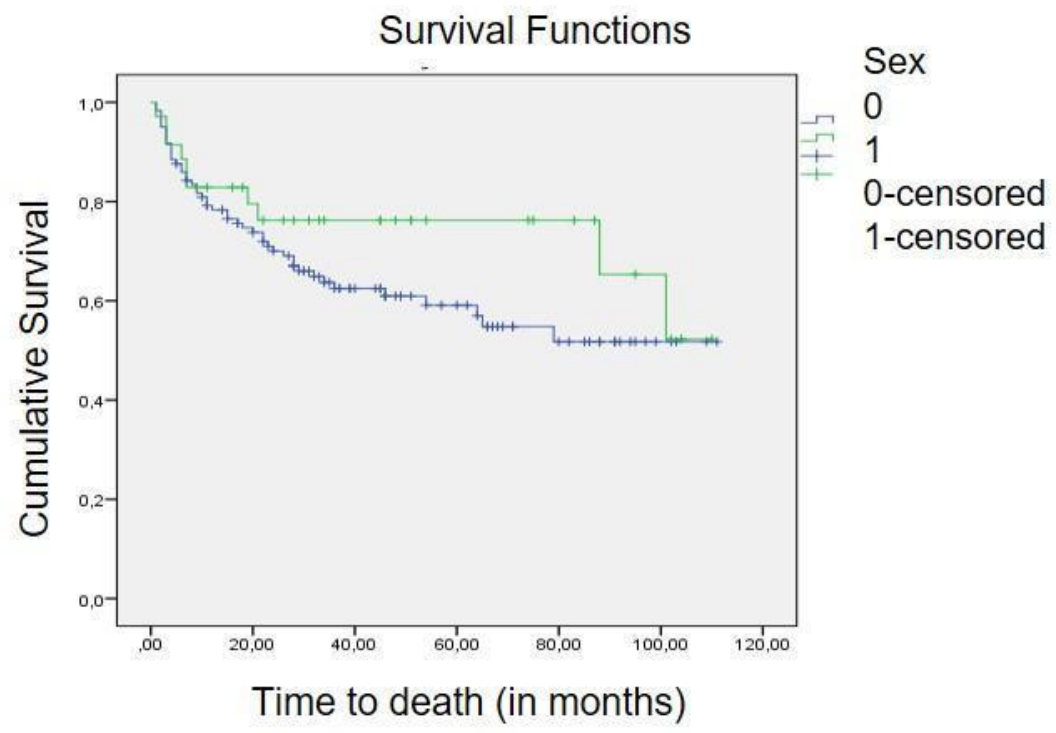

Comparisons among age, sex, ethnicity, and anatomical location of the CA showed no significant differences for survival times; however, survival times were shorter for patients in their seventh decade of life (67.592 months) and longer for patients in their fifth decade of life (74.207) ( $\mathrm{p}=0.169)$, It was lower in males $(69.671$ months), when compared to females (79.676 months) $(\mathrm{p}=0.25)$,. In addition, survival times were shorter in non-white patients (47.9 months) than in white patients $(72.2$ months $)(p=0.86)$ and 
were longer for patients with mouth CA (71.6 months) than for patients with CA of the oropharynx (68.8 months) $(\mathrm{p}=0.792$ (Table 6).

Table 6. Distribution of survival time of patients with malignant neoplasms in the mouth and oropharynx according to age, ethnicity, sex and location according to Log Rank (Mantel-Cox) analysis. Rio de Janeiro, Brazil,from 2007 to 2017

\begin{tabular}{lcc}
\hline Variables & $\begin{array}{c}\text { Estimates } \\
\text { (months) }\end{array}$ & P value $(0.05)$ \\
\hline Age & 71,1 & \\
$\leq 49$ & 74,2 & 0,169 \\
$50-59$ & 70,5 & \\
$60-69$ & 67,5 & \\
$\geq 70$ & & 0,086 \\
Ethnicity & 72,2 & \\
White & 47,9 & \\
No White & & 0,250 \\
Sex & 69,6 & \\
Male & 79,6 & 0,792 \\
Female & & \\
Location & 71,6 & \\
Mouth & 68,8 & \\
Oropharyngeal & & \\
\end{tabular}

\section{DISCUSSION}

Mouth and oropharyngeal CA remain challenging for the scientific community due to their high prevalences and mortalities, their low survival rates and the large impacts they have on the quality of life of all involved, which make these CAs global public health problems (WAMAKULASURIYA, S, 2010; BOING, AF \& ANTUNES, JLF, 2011; SANTOS, IV, et al., 2011; OMS, 2019).

In the present study, we evaluated patients with mouth and oropharyngeal CA who were treated at the Salgado Filho Municipal Public Hospital, located in Méier, Rio de 
Janeiro, Brazil, from 2007 to 2017, and we developed an epidemiological profile of these patients and analyzed their survival rates. Most of these patients came from the city of Rio de Janeiro, which demonstrates the importance of the service to the affiliated population.

The results of current study revealed that mouth and oropharyngeal CAs are more prevalent in men than in women, which is in line with the results reported by Le Campion et al. (2017) and López-Soto et al. (2018). This increased prevalence may be due to behavioral factors, as men are more exposed to more risk factors than women. However, studies performed by Gérvasio et al. (2001) and Emanuele and Fontanella (2009) show that the prevalence is increasing among women because they are consuming more alcohol and tobacco.

Mansour, S, et al. (2003) reported results similar to those of present study with regards to age. The patients in their study had a mean age of $61.2 \pm 13.3$ years, with the fifth decade of life being the most prevalent, which is in line with the results reported by Neves et al., (2014) and Moro et al. (2018). Schneider et al. (2014) and Fernandes and Fraga (2019) also observed an increased risk of developing CA with increasing age, likely due to the comorbidities associated with individuals in advanced age groups and increased exposure to risk factors, which is in line with the data obtained in the present study. Peralta et al. (2017) considered the elderly to be at high risk for the development of neoplasms. Gilyoma et al. (2015) reported a younger age trend, with a mean age of 42 years in their study.

Regarding ethnicity, the present study presented similar results for whites, browns and blacks; however, when the study sample was dichotomized into whites and non-white, a higher frequency was observed for non-whites compared with whites, which is similar to the findings of Le Campion et al. (2016), Neves et al. (2017) and López-Soto et al. (2018). However, Perez et al. (2007) and Moro et al. (2018) reported different results, and these discrepancies are likely due to the different geographic regions of the studies.

Our study found that oral SCC was the most prevalent type of CA lesion, similar to the results of other studies (LE CAMPION, ACOV, et al., 2016; PERALTA, MM, et al., 2017; MORO, JS, et al., 2018). The lateral tongue was the most affected region, with no significance differences between the right and left sides, followed by the buccal floor, similar to what has been reported by Perez et al. (2007), Bonfante et al. (2014), Pontes et 
al. (2014). Costa et al. (2002) studied a hospital in the city of Natal (RN) and report the lower lip region as the having the highest CA occurrence, likely due to the high solar radiation index to which the population of that region is exposed. In addition, Perez et al. (2007) reported the floor of the mouth as being the most prevalent region, followed by the lingual region.

This study showed that an isolated smoking habit, considered by Bittencourt et al. (2017) to be a public health problem, was the primarily risk factor identified for the occurrence of mouth and oropharyngeal tumors; however, the concomitant intake of alcoholic beverages and cigarettes also presented a high prevalence, which has also been well-established in the literature. Our study reinforces that alcohol consumption in conjunction with smoking should be a concern, as this association plays a strong role in increasing the risks of oral cavity CA (FARSHADPOUR, F, et al., 2007; BECKEL, HD, et al., 2013); however, Mansour et al. (2003) reported that the use of alcohol was more frequent when compared to smoking but that other factors, such as nutrition, cellular activity levels, access to medical care and comorbidities, may be related to the consumption of alcohol and/or cigarettes and should not be discarded.

According to Sobral et al. (2014) and Mourad et al. (2017) there is a close relationship between the human papillomavirus (HPV) and mouth and oropharyngeal CA; however, Soares and Pereira (2019) declared that there is no consensus in the literature on role played by HPV in the carcinogenesis of these CAs. In this study, it was not possible to analyze this relationship due to lack of information regarding HPV status in the medical records.

In our study, mouth CA occurred more frequently than oropharyngeal CA, a finding which is similar to those reported by Le Campion et al. (2017) and Moro et al. (2018). This result is likely due to the fact that the mouth is the first location to experience contact with tobacco and alcohol. In addition, this hospital has an active otorhinolaryngology service, which works in a multidisciplinary method with the stomatology service, and cases of oropharyngeal lesion can be referred to this hospital directly, without going through the dentistry service. However, studies by López-Soto et al. (2018) show that, although these types of lesions are less frequent, they are more complex lesions and are more often diagnosed during more advanced stages, due to the difficulty of visualization and access. 
According to Warnakulasuriya (2010), in most countries, the overall five-year survival rates for CAs of the tongue, oral cavity and oropharynx are approximately 50-60\%. The best result is for lip CA, with more than $90 \%$ of patients surviving for five years. In general, the prognosis decreases with increases in disease progression, age and lifestyle risks.

In the present study, the 5-year survival rate was similar to that reported by Bonfante et al. (2014) and López-Soto et al. (2018), who reported rates of $60 \%$ and $62.5 \%$, respectively; however, our results were better than those reported by Schneider et al. (2014), of 33.3\%, and Moro et al. (2018), of 42\%. In addition, it was possible to estimate an overall survival rate of approximately 6 years for mouth CA (72 months). In a study by Moro et al. (2018), the mean survival time was 4 years. Our study also showed that, when categorizing the survival rate by the anatomical location of the tumor, those located in the oropharynx had shorter survival rates than those located in the mouth.

Hessel et al. (2000) found a 5-year overall survival rate of $68.6 \%$ for patients with SCC in the tongue, who were diagnosed at T1-2 and N0-1 and were treated at the University of Texas (Houston, USA), which is better than the survival rate found in the present study. The results reported by Hessel et al. can be explained by early diagnosis, rapid access to specialized services, and appropriate treatment.

According to Oliveira et al. (2008) the association reduced survival time and increased age is likely due to the presence of comorbidities and other complications typical of aging.

However, the data reported by Megwalu and Ma (2017) and De Souza Santos et al. (2018) demonstrate the significant influence of ethnicity on the survival of patients with oropharyngeal CA, likely due to precarious socioeconomic conditions that make access to treatment difficult and result in black patients suffering from reduced survival rates.

Malignant tumors in the mouth presented better survival rates than those of the oropharynx, as facilitated access contributes to earlier diagnoses and better treatment, which can both increase survival. In addition, oropharyngeal tumors are associated with cervical metastases, with an incidence of 50 to $70 \%$, likely due to the presence of a rich lymphatic network, which favors the spread of the tumor (BECKER, 2000; DE SOUZA SANTOS et al., 2018). 


\section{CONCLUSION}

The patients treated at the Municipal Hospital Salgado Filho, in Rio de Janeiro, for mouth and oropharynx CA are most commonly male, non-white, in their fifth decade of life, and smokers. The most common CA type is an SCC tumor located on the lateral region of the tongue, on the left side. The survival rate found in this study was similar to those reported for developed countries; however, tumors located in the oropharynx had worse survival rates compared with those in the mouth.

\section{REFERÊNCIAS}

1. INCA - Instituto Nacional de Câncer [Internet]. INCA - Instituto Nacional de Câncer. 2019 [cited 19 February 2019]. Available from: http://www2.inca.gov.br/wps/wcm/connect/tiposdecancer/site/home/boca/defini $\underline{\mathrm{caO}}$

2. Boing AF, Antunes JLF. Condições socioeconômicas e câncer de cabeça e pescoço: uma revisão sistemática de literatura. Ciênc. Saúde Coletiva. 2011; 16(2): 615-622.

3. Neville B. Patologia Oral e Maxilofacial. London: Elsevier Health Sciences Brazil; 2016.

4. Andrade J, Santos C, Oliveira M. Fatores associados ao câncer de boca: um estudo de caso-controle em uma população do Nordeste do Brasil. Revista Brasileira de Epidemiologia. 2015; 18(4): 894-905.

5. Sobral APV, Almeida HCR, Fontes JPS. Correlação do Papilomavírus Humano com o Carcinoma Epidermoide Bucal: Revisão Sistemática. Rev. cir.traumatol. buco-maxilo-fac. 2014; 14(2): 95-102.

6. Souza Torres SV; Sbegue A; Botelho Costa SC. RevSocBrasClin Med. 2016 janmar;14(1):57-62 
7. Casotti E, Monteiro AF, Castro Filho EL, Santos MP. Organização dos serviços públicos de saúde bucal para diagnóstico precoce de desordens com potencial de malignização do estado do Rio de Janeiro, Brasil. Ciênc. saúdecoletiva. 2016; $21(5): 1573-1582$.

8. Warnakulasuriya S. Living with oral cancer: Epidemiology with particular reference to prevalence and life-style changes that influence survival. Oral Oncology. 2010;46(6):407-410.

9. Santos IV, Alves TDB, Falcão MML, Freitas VS. O papel do cirurgião-dentista em relação ao câncer de boca. Odontol. Clín.-Cient.2011 ; 10 ( 3 ): 207-210.

10. OMS - Organização Mundial de Saúde [Internet]. Paho.org. 2019 [cited 20 February 2019]. Available from: https://www.paho.org/bra.../index.php?option=com_content\&view=article\&id=5 588:folha-informativa-cancer\&Itemid=1094

11. Le Campion ACOV, Santos KCB, Carmo ES, Silva Júnior FF, Peixoto FB, Ribeiro CMB et al. Caracterização do atraso no diagnóstico do câncer de boca e orofaringe em dois centros de referência. Cad. Saúde colet. 2016; 24(2): 178-184.

12. López-Soto A, Pinheiro L, De Abreu M, De Andrade Sousa A, Caldeira P, De Aguiar M. Oral and Oropharyngeal Cancer in Belo Horizonte: Hospital-Based Study From 2005 to 2015. Oral Surgery, Oral Medicine, Oral Pathology and Oral Radiology. 2018;126(3):e158.

13. Gervásio OL., Dutra RA., Tartaglia SM, Vasconcellos WA, Barbosa AA, \& Aguiar MC. Oral squamous cell carcinoma: a retrospective study of 740 cases in a Brazilian population. Braz Dent J. 2001; 12(1), 57-61. 
14. Emanuele Werner J, Fontanella V. Perfil epidemiológico dos pacientes portadores de câncer bucal atendidos no Hospital Santa Rita, Porto Alegre/RS. Stomatos. 2009;15(28):3-16.

15. Mansour O, Snyderman C, DAmico F. Association Between Tobacco Use and Metastatic Neck Disease. The Laryngoscope. 2003;113(1):161-166.

16. Neves C, Raposo A, Bezerra P. Perfil dos Pacientes com Diagnóstico de Câncer de Cabeça e Pescoço atendidos em Hospital Especializado de Recife - PE, no ano de 2014. Id onLine REVISTA DE PSICOLOGIA. 2017;11(37):685-698.

17. Moro JS, Maroneze MC, Ardenghi TM, Barin LM, Danesi CC. Oral and oropharyngeal cancer: epidemiology and survival analysis. Einstein (São Paulo). 2018; 16(2): eAO4248.

18. Schneider IJC, Flores MEl, Nickel DA, Martins LGT, Traebert J. Survival rates of patients with cancer of the lip, mouth and pharynx: a cohort study of 10 years. Rev. bras. epidemiol. 2014; 17(3): 680-691.

19. Fernandes IS; Fraga CPT. A importância do cirurgião dentista nos efeitos adversos na cavidade bucal do tratamento oncológico de cabeça e pescoço. Revista Científica UMC. 2019; 1(4).

20. Peralta MM, De Lourdes Caldana M, Da Silva Bastos R., De Magalhães Bastos JR, \& Honório HM. Neoplasias bucais em indivíduos idosos no Brasil: Revisão integrativa. Revista Rede de Cuidados em Saúde. 2017;10(1):1-18.

21. Gilyoma J, Rambau P, Masalu N, Kayange N, Chalya P. Head and neck cancers: a clinico-pathological profile and management challenges in a resource-limited setting. BMC Research Notes. 2015;8(1). 
22. Perez RS, Freitas SM, Dedivitis RA, Rapoport A, Denardin OVP, Sobrinho JA, et al. Epidemiologic Study of Squamous Cell Carcinoma of the Mouth and Oropharynx. Int. Arch. Otorhinolaryngol. 2007;11(3):271-277.

23. Bonfante G, Machado C, Souza P, Andrade E, Acurcio F, Cherchiglia M. Sobrevida de cinco anos e fatores associados ao câncer de boca para pacientes em tratamento oncológico ambulatorial pelo Sistema Único de Saúde, Brasil. Cadernos de Saúde Pública. 2014;30(5):983-997.

24. Pontes, H. Criação de uma rede de proteção contra o carcinoma epidermóide em estágio avançado no Estado do Pará.Comunicação Em CiêNcias Da SaúDe. 2018;28(01), 102-106.

25. Costa ALL, Pereira JC, Nunes AAF, Arruda MLS. Correlação entre a classificação TNM, gradação histológica e localização anatômica em carcinoma epidermóide oral. Pesqui. Odontol. Bras. 2002; 16(3): 216-220.

26. Bittencourt CP et al. Tabagismo e sua relação com o desenvolvimento de câncer. Revista Científica do ITPAC, Araguaína. 2017; 10(1):13-18.

27. Beckel Hendges D, Stoll R, \& Moreschi, C. A influência de hábitos e estilo de vida no surgimento de neoplasias malignas - uma revisão de literatura. Revista Destaques Acadêmicos. 2013; 5(3).

28. Farshadpour F, Hordijk G, Koole R, Slootweg P. Non-smoking and non-drinking patients with head and neck squamous cell carcinoma: a distinct population. Oral Diseases. 2007;13(2):239-243.

29. Mourad M, Jetmore T, Jategaonkar A, Moubayed S, Moshier E, Urken M. Epidemiological Trends of Head and Neck Cancer in the United States: A SEER Population Study. Journal of Oral and Maxillofacial Surgery. 2017;75(12):25622572. 
30. Soares, ACR; Pereira CM. Associação do HPV e o Câncer Bucal. Revista Ciências e Odontologia. 2018; 2(2): 22-27.

31. Hessel A, Moreno M, Hanna E, Roberts D, Lewin J, El-Naggar A et al. Compliance with quality assurance measures in patients treated for early oral tongue cancer. Cancer. 2010;116(14):3408-3416.

32. Oliveira L, Ribeiro-Silva A, Costa J, Simões A, Matteo M, Zucoloto S. Prognostic factors and survival analysis in a sample of oral squamous cell carcinoma patients. Oral Surgery, Oral Medicine, Oral Pathology, Oral Radiology, and Endodontology. 2008;106(5):685-695.

33. Megwalu U, Ma Y. Racial disparities in oropharyngeal cancer survival. Oral Oncology. 2017; 65:33-37.

34. De Souza Santos LP, Neto BCB, Pimenta RMC, \& Miranda SS. Analysisofthe role ofrace/skin color in theprognosisofcancerofthe oral cavityandoropharynx. JournalofDentistry\&Public Health. 2018:9(2), 170-179.

35. Becker M. Oral cavity, oropharynx, and hypopharynx. Seminars in Roentgenology. 2000;35(1):21-30. 